\title{
Digestive Proteases From Fish Processing Wastes: Their Partial Characterization and Comparison
}

Ivana Soledad Friedman

Instituto de Investigaciones Marinas y Costeras (IIMyC), Facultad de Ciencias Exactas y Naturales (FCEyN), Universidad Nacional de Mar del Plata (UNMdP) Consejo Nacional de Investigaciones Científicas y Tecnológicas (CONICET). Funes 3250,7600 Mar del Plata

Leonel Agustín Behrens

Instituto de Investigaciones Marinas y Costeras (IIMyC), Facultad de Ciencias Exactas y Naturales (FCEyN), Universidad Nacional de Mar del Plata (UNMdP) Consejo Nacional de Investigaciones Científicas y Tecnológicas (CONICET). Funes 3250,7600 Mar del Plata

Nair A Pereira

Instituto de Investigaciones Marinas y Costeras (IIMyC), Facultad de Ciencias Exactas y Naturales (FCEyN), Universidad Nacional de Mar del Plata (UNMdP) Consejo Nacional de Investigaciones Científicas y Tecnológicas (CONICET). Funes 3250,7600 Mar del Plata

Edgardo Contreras

Instituto de Investigaciones en Ciencia y Tecnología de Materiales (INTEMA), CCT - Mar del Plata CONICET, Av. Juan B. Justo 4302,7600 Mar del Plata, Argentina

Analia Verónica Fernández-Gimenez ( $\sim$ fgimenez@mdp.edu.ar)

Instituto de Investigaciones Marinas y Costeras https://orcid.org/0000-0001-9232-4560

\section{Research}

Keywords: fish wastes, viscera, proteases, biotechnology

Posted Date: July 28th, 2020

DOl: https://doi.org/10.21203/rs.3.rs-45716/v1

License: (c) (i) This work is licensed under a Creative Commons Attribution 4.0 International License. Read Full License

Version of Record: A version of this preprint was published at Journal of Fish Biology on October 21st, 2021. See the published version at https://doi.org/10.1111/jfb.14929. 


\section{Abstract}

Fish processing generates a lot of wastes which are discarded resulting in environmental problems. However, this material represents a significant source of high-value bioproducts with potential biotechnological applications. The objective of this study was to characterize and to compare specific activities of acid and alkaline proteases recovered from the viscera of Merluccius hubbsi (Mh), Percophis brasiliensis (Pb), Urophyis brasiliensis (Ub), and Cynoscion guatucupa $(\mathrm{Cg})$ under different $\mathrm{pH}$ and temperature conditions. Stomach proteinases from four species had a higher activity at $\mathrm{pH} 2$, with stability in the range of $\mathrm{pH} 2-4$. Optimum $\mathrm{pH}$ from intestinal enzymes of $\mathrm{Cg}$ was 11.5 , while for the crude extract of $\mathrm{Mh}, \mathrm{Pb}$, and $\mathrm{Ub}$ catalytic activity was registered over a wide $\mathrm{pH}$ range range from 7 to 11.5 . Stomach proteinases from four studied species had a higher activity at $30^{\circ} \mathrm{C}$ and $50^{\circ} \mathrm{C}$, with stability at $10{ }^{\circ} \mathrm{C}$ and $30^{\circ} \mathrm{C}$. Optimum temperature from intestinal enzymes of the four tested species was $50^{\circ} \mathrm{C}$ with high stability at $10^{\circ} \mathrm{C}$ and $30{ }^{\circ} \mathrm{C}$. Alkaline proteinase from all species and acid proteinases from $\mathrm{Cg}$ was inactivated at $70^{\circ} \mathrm{C}$, while stomach enzymes of $\mathrm{Mh}, \mathrm{Pb}$, and $\mathrm{Ub}$ had a residual activity lower than $5 \%$ at $80{ }^{\circ} \mathrm{C}$ after 5,10 y 20 minutes of pre-incubation, respectively. Digestive proteinases recovered in this study could be used as biocatalysts in industrial processes, reducing costs, adding value to the fishery waste, and contributing to the reduction of environmental pollution.

\section{Introduction}

Fish and fishery products are some of the most commercialized foods in the world and they represent a valuable bioresource of nutrients to obtain diversified and healthy diets. Total fish production in the world reached an all-time high of 171 million tonnes in 2016 and is expected to reach 201 million tonnes in 2030 (FAO 2018). However, 70\% of fish used in industrial processing is discarded as processing leftover, generating a lot of wastes and other by-products (Olsen et al. 2014). This solid waste includes heads, skins, trimmings, fins, scale, viscera, and bones (Sahu et al. 2016). Although a fraction of this waste is used to the elaboration of fishmeal (Mo et al. 2018), large amounts of this generated solid waste is not used and is directly discarded on open-air dumps or water sources (Pereira and Fernández-Gimenez 2016). Fishery by-products and wastes extracted from inexpensive marine feedstock may have even higher in value than the starting material, so, it is necessary to identify techno-economic viability for recycling of these wastes (Oliveira et al. 2017).

Proteases are the most widely used group of enzymes in industrial bioprocesses so they represent about $40-65 \%$ of the total commercial enzyme preparations (Atta et al. 2017). In this sense, fish viscera are one of the most important wastes because they contain digestive enzymes, especially aspartic proteases (pepsin) in stomach, and serine proteases (trypsin, chymotrypsin, collagenase, and elastase) in intestine and pyloric ceca (Klomklao et al. 2011; Vannabun et al. 2014; Välimaa et al. 2019). These digestive proteinases have unique properties compared with their counterpart enzymes from land animals. Some of their distinctive features include greater stability over a wide range of $\mathrm{pH}$, higher catalytic efficiency, and thermostability at low temperatures (Aspevik et al. 2017). These characteristics have become suitable for different applications in many food-processing operations (Oliveira et al. 2017).

There are some studies about commercial applications for enzymes recovered from fish by-products (Kim and Dewaprya 2014) where the development of new and improved technologies have allowed that these enzymes can be used more efficiently in several processes (FAO 2018).

Fish enzymes present in these by-products are able to catalyze reactions without additional thermal aid, reducing manufacturing cost, and allowing the development of products with more consistent properties (Kuddus 2018). These natural products are more accepted than the corresponding synthetic ones because they are considered safer by consumers (Ferraro et al. 2013).

Argentina has 4,700 km of coastline on the Argentine Sea over the Southern Atlantic Ocean, making fishing a significant economic activity with various fishing resources, being the demersal resources among the most important ones. Merluccius hubbsi is one of the main fishing resources with captures about 417 mil tonnes in 2018 and this species represents $50 \%$ of the total fish catches (Allega et al. 2019). On the other hand, the captures of Percophis. brasiliensis and Cynoscion guatucupa were 56,575 tonnes in 2018 (Prosdocimi et al. 2019). These species are actively fished as they are commercialized in the international market as frozen fillet, headless, and gutted and Mar del Plata (Argentina) is the main landing port supplied (Irusta et al. 2016). However, discards of these species represent rising volumes of by-products that emerged by fishery processing and have serious environmental-security implications. On the other hand, P. brasiliensis, C. guatucupa and Urophyis brasiliensis are fished as by-catch of the target species such as M. hubbsi (Bovcon et al. 2013). For this reason, a description of operational parameters and biochemical characteristics of enzymes recovered from fish wastes is necessary to revalue these discards, power market them, and to ensure a profitable utilization at industrial scale. Biochemical parameters of enzymes often constrained the operational limits of the biotechnological process (van Beilen and Li 2002). Therefore, the characterization of enzymes is crucial for correct process design and useful for understanding their types, modes of action, and activity values. The effect of $\mathrm{pH}$ and temperature on the enzymatic activity is evaluated with the affinity for specific substrates in most studies (Martínez-Cárdenas et al. 2017). Until now, there are no comparative studies evaluating the potential of the digestive enzymes present in fish wastes from actively commercialized species.

Scarce previous researches focused on digestive enzymes of Argentine fish species. In this sense, trypsin from the viscera and heads of $M$. hubbsi (Lamas et al. 2015) and Engraulis anchoita (Lamas et al. 2017) and digestive aspartic proteases from Prochilodus lineatus (Gomez et al. 2018) have been characterized.

The aim of this study was to characterize and to compare specific activities of acid and alkaline proteases under different pH and temperature conditions recovered from wastes generated during the processing of Merluccius hubbsi, Percophis brasiliensis, Urophyis brasiliensis, and Cynoscion guatucupa.

\section{Materials And Methods}

Fish samples

Stomach, small intestine and pyloric ceca of Merluccius hubbsi (Mh) and Percophis brasiliensis (Pb) were provided by Pinapesca S.A., Mar del Plata, Argentina. Cynoscion guatucupa $(\mathrm{Cg})$ and Urophyis brasiliensis $(\mathrm{Ub})$ were fished from Mar del Plata coast $\left(38^{\circ} 04^{\prime} \mathrm{S}, 57^{\circ} 30^{\prime} \mathrm{W}\right)$ by commercial fleet and viscera 
were extracted immediately. Viscera of four adult fishes of each species were used. All samples were frozen and transported to Mar del Plata National University for analysis.

Preparation of crude extracts

Stomach, intestine and pyloric ceca were separated and crushed in a glass-teflon tissue homogenizer with distilled water for intestine-ceca, or with water adjusted to $\mathrm{pH} 2$ using $0.1 \mathrm{~N} \mathrm{HCL}$ in stomachs $(1: 4 \mathrm{w} / \mathrm{v})$. The resulting materials were centrifuged at $10,000 \mathrm{~g}$ for $30 \mathrm{~min}$ at $4{ }^{\circ} \mathrm{C}$ (Presvac EPF $\left.12 \mathrm{R}\right)$. The supernatants were separated and stored as crude extracts for all the enzymatic assays. Enzymatic extracts from intestine and pyloric ceca were frozen at $-20^{\circ} \mathrm{C}$. Extracts from stomachs were maintained overnight at $4{ }^{\circ} \mathrm{C}$ to activate the pepsinogen, and then at $-20^{\circ} \mathrm{C}$ until use.

Enzymatic assays

Protein content was determined by Bradford (1976) method, using bovine serum albumin (Sigma A9647) as standard protein, and it was expressed as mg protein $/ \mathrm{mL}$ crude extract.

Acid proteinase activity was determined at pH 2 using stomach samples, according to Anson (1938). Briefly, $5 \mu \mathrm{L}$ of each crude extract was mixed with $250 \mu \mathrm{L}$ of universal buffer $\mathrm{pH} 2$ (Stauffer 1989) in Eppendorf tubes and $250 \mu \mathrm{L}$ of $0.5 \% \mathrm{w} / \mathrm{v}$ hemoglobin (Sigma H2625) as substrate. The mixture was incubated $30 \mathrm{~min}$ at $25^{\circ} \mathrm{C}$. Then, the reaction was stopped by adding $250 \mu \mathrm{L}$ of $20 \% \mathrm{w} / \mathrm{v}$ trichloroacetic acid (TCA). After that, all tubes were centrifuged at $10,000 \mathrm{~g}$ for $5 \mathrm{~min}$ and absorbance of the supernatants was measured at $280 \mathrm{~nm}$ in a spectrophotometer (SPECTROstar Nano BMG LABTECH).

Alkaline proteinase activity on intestine-ceca samples was measured according to García-Carreño (1992) using a similar protocol above mentioned using azocasein (Sigma A2765) as the substrate, and universal buffer at $\mathrm{pH} 8$. In this case, the absorbance of the supernatants was measured at $360 \mathrm{~nm}$.

All assays were performed in triplicates. Trichloroacetic acid was added in blanks tubes before the substrate was supplied. A unit of enzymatic activity (U) was defined as a change in absorbance per minute. Total activity (TA) was expressed as $\mathrm{U} / \mathrm{mL}$ of crude extract, and the specific enzyme activity (SA) as $\mathrm{U} / \mathrm{mg}$ of soluble protein.

For determining the optimum $\mathrm{pH}$, the proteinase activity was assayed at $\mathrm{pH} 2,3$, and 4 for stomach samples, and pH 7, $8,9.5$ and 11.5 for intestine-ceca samples. In all cases, the universal buffer was used (Stauffer 1989). The substrate (azocasein or hemoglobin) was dissolved in each of the pH buffer solutions, and the protocol was followed as described above. The effect of $\mathrm{pH}$ on the stability of proteinases was evaluated by pre-incubating the crude extracts at different times $(30,60$, and $150 \mathrm{~min})$ in the above mentioned buffer. Then, the enzymatic activities were measured as described previously.

For determining the optimum temperature, the enzyme activity at $\mathrm{pH} 2$ for stomach samples and $\mathrm{pH} 8$ for intestine-ceca samples, was assayed at $10,30,50$, and $70^{\circ} \mathrm{C}$. In order to establish the thermal stability, prior to enzymatic activity, a mix of $5 \mu \mathrm{L}$ of crude extract and $250 \mu \mathrm{L}$ of adequate buffer was incubated for 30,60 , and $150 \mathrm{~min}$ at the above mentioned temperatures. Then, the substrate solution was added and the protocol was continued as described above.

In the cases where the enzymes still had activity at $70{ }^{\circ} \mathrm{C}$ for $150 \mathrm{~min}$, a denaturation assay was performed. Firstly, enzymatic activity was determined in buffer universal at pH 2 or $\mathrm{pH} 8$, depending on the sample. Then, all the tubes were pre-incubated at 80 and $90^{\circ} \mathrm{C}$ for 5,10 , and 20 min. Finally, the respective substrate solution was added and the protocol was continued as described above. Enzymes were considered denatured when the residual enzymatic activity was less than $5 \%$ with respect to their initial values.

Statistics

Data sets were presented as the mean and standard error. After testing data normality and homogeneity of variance, differences among data sets were analyzed by ANOVA followed by a Tukey's multicomparison test. Differences are reported as statistically significant when $\mathrm{p} \otimes 0.05$. Analyses were made using R Studio Software (v.1.2.5033; RStudio Team 2016) and R Commander (v.3.6.2; R Development Core Team 2015).

\section{Results And Discussion}

Enzymatic activity

The viscera from fish wastes, which includes stomach, small intestine, and pyloric ceca, are characterized by being the richest source of digestive proteolytic enzymes (Khantaphant and Benjakul 2008; Klomklao 2008; Simpson 2000).

In present work, specific enzymatic activity on U. brasiliensis (Ub) stomach extract was significantly higher than the other studied species. However, for intestine-ceca crude extracts, specific enzymatic activity evidenced the highest activities for $\mathrm{Ub}$ and $P$. brasiliensis (Pb). Besides, total enzymatic activity for intestine-ceca crude extracts exhibited the highest activity for $\mathrm{Pb}$ (Table 1). 
Table 1

Total activity (TA), specific activity (SA) and soluble protein (SP) of stomach and intestine of fishes.

\begin{tabular}{|c|c|c|c|c|c|}
\hline & & Mh & $\mathrm{Pb}$ & Ub & $\mathrm{Cg}$ \\
\hline \multirow[t]{3}{*}{ Stomach } & $\mathrm{TA}^{*}$ & $1.77 \pm 0.570^{a}$ & $1.43 \pm 0.162^{a}$ & $1.55 \pm 0.525^{a}$ & $1.15 \pm 0.263^{a}$ \\
\hline & $S A^{\star \star}$ & $0.50 \pm 0.137^{a}$ & $1.90 \pm 0.464^{\mathrm{ab}}$ & $7.26 \pm 3.043^{b}$ & $0.38 \pm 0.094^{a}$ \\
\hline & $\mathrm{SP} * \star \star$ & $3.90 \pm 1.540^{b}$ & $0.87 \pm 0.172^{a}$ & $0.24 \pm 0.091^{a}$ & $3.26 \pm 0.903^{b}$ \\
\hline \multirow[t]{3}{*}{ Intestine-Ceca } & $\mathrm{TA}^{*}$ & $0.75 \pm 0.362^{a}$ & $3.46 \pm 0.353^{b}$ & $0.65 \pm 0.095^{a b}$ & $0.25 \pm 0.063^{a}$ \\
\hline & $S A^{\star \star}$ & $0.31 \pm 0.133^{a}$ & $1.82 \pm 0.437^{b}$ & $1.40 \pm 0.266^{b}$ & $0.15 \pm 0.041^{a}$ \\
\hline & $\mathrm{SP} \star \star \star \star$ & $2.49 \pm 0.344^{a}$ & $2.01 \pm 0.228^{a b}$ & $0.49 \pm 0.064^{b}$ & $1.79 \pm 0.410^{\mathrm{ab}}$ \\
\hline
\end{tabular}

Previous studies have shown that the digestive enzyme activity has a correlation with feeding habits of fishes (Falcón-Hidalgo et al. 2011; Gioda et al. 2017; Martínez-Cárdenas et al. 2017; Pujante et al. 2017). All species studied in this work are carnivorous; Mh is a generalist and opportunistic predator that feeds mainly on demersal fishes, followed by crustaceans and cephalopods (Alonso et al. 2019), while Ub is a generalist that feeds mainly on shrimp, crabs, shellfish and shrimp is its main prey (Plavan et al. 2007). On the other hand, $\mathrm{Cg}$ has a varied diet that changes throughout its development, first, feed on small crustaceans and progressively increase their consumption of fish (Viola et al. 2018) whereas Pb feeds mainly on fish and squid (Milessi and Marí 2012). For this feeding habit, digestion of proteins occurs in the stomach with a high acid proteinase activity such as pepsin. The hydrolysis of protein is finalized in the intestine with the release of amino acids and peptides where alkaline proteinases usually have a lower activity (Xiong et al. 2011; Jesús-Ramirez et al. 2017; Martínez-Cárdenas et al. 2017; Merino-Contreras et al. 2018). This can be corroborated with results showed in Table 1 for Mh, Cg, and Ub, where stomach proteinase activity was higher than intestine enzyme activity. However, $\mathrm{Pb}$ evidenced higher activity of intestinal-ceca proteinases. Similar results were reported for other carnivorous species, such as rainbow trout Oncorhynchus mykiss (Hidalgo et al. 1999) where intestinal proteolytic activity was higher than the stomach enzyme activity.

Martínez et al. (2011) proposed the relative activity of the main digestive alkaline proteases as an indicator of the nutritional status of the fish. These authors demonstrated that a high trypsin and chymotrypsin activity has been correlated with the presence of a diet with an adequate protein constitution, while a low value correlates with food shortage. Thus, the discrepancy in the enzymatic activity between species may be due to the feed condition of fish at a presampling time (Natalia et al. 2004).

Optimum pH and stability of proteinase activities

The effect of $\mathrm{pH}$ on stomach proteinase activities are shown in Table 2A. While optimum $\mathrm{pH}$ for enzymes of $\mathrm{Pb}$ was $\mathrm{pH} 2$, in the case of $\mathrm{Mh}$ and $\mathrm{Ub}$ were $\mathrm{pH} 2$ and $\mathrm{pH}$ 3. Stomach enzymes of $\mathrm{Cg}$ had similar activity values for all tested $\mathrm{pH}$. The stability of stomach enzymes at acid $\mathrm{pHs}$ was evaluated at different times of pre-incubation. Acid proteinases from all fishes tested were highly stable in the range of $\mathrm{pH} 2-4$. After 150 minutes of pre-incubation, the enzymes of all species kept their activity. All values did not show significant differences at different time incubation. Similar results were found in viscera of Monterey sardine (Sardinops sagax caerulea) (Castillo-Yañez et al. 2004) and sábalo (Prochilodus lineatus) (Gomez et al. 2018). However, the highest values for acid proteinase activity were higher at $\mathrm{pH} 3$ for acid proteinases extracted from viscera of other species as farmed giant catfish (Pangasianodon gigas) (Vannabun et al.

2014) and golden grey mullet (Liza aurata) (Bkhairia et al. 2016).

The effect of $\mathrm{pH}$ on intestine-ceca proteinase activities are shown in Table 2B. Optimum $\mathrm{pH}$ for enzymes of $\mathrm{Cg}$ was 11.5 , while for the crude extracts of $\mathrm{Mh}$, $\mathrm{Pb}$, and $\mathrm{Ub}$, the catalytic activity was almost constant over a wide $\mathrm{pH}$ range from 7 to 11.5 , without significant differences. The stability of enzymes at alkaline $\mathrm{pHs}$ was evaluated with different times of pre-incubation. The $\mathrm{pH}$ stability profile showed that alkaline proteinases from all species were highly stable within the tested range of $\mathrm{pH}$. After 150 minutes of pre-incubation, the enzymes of all species kept their catalytic activity, and their values did not show significant differences at different time incubation. Similar results were reported for seer fish (Scomberomorus guttatus) (Rengasamy et al. 2016), farmed giant catfish ( $P$. gigas) (Vannabun et al. 2014), chihuil sea catfish (Bagre panamensis) (Rios-Herrera et al. 2019), Indian oil sardine (Sardinella longiceps) (Ramkumar et al. 2018) and greater amberjack (Seriola dumerili) (Oliveira et al. 2017).

\section{Table 2}

Table 2. Specific proteinase activity at different conditions of $\mathrm{pH}$ for stomach (A) and intestine-ceca extracts (B) 


\begin{tabular}{|c|c|c|c|c|}
\hline \multirow[t]{2}{*}{ SPECIES } & \multirow{2}{*}{$\begin{array}{l}\text { time } \\
(\min )\end{array}$} & \multicolumn{3}{|l|}{$\mathrm{pH}$} \\
\hline & & 2 & 3 & 4 \\
\hline \multirow[t]{4}{*}{ Mh } & 0 & $0.49 \pm 0.137^{\mathrm{aA}}$ & $0.25 \pm 0.093^{\mathrm{aA}}$ & $0.11 \pm 0.029 \mathrm{aA}$ \\
\hline & 30 & $0.46 \pm 0.153^{\mathrm{aA}}$ & $0.26 \pm 0.073 \mathrm{aA}$ & $0.09 \pm 0.031^{\mathrm{aA}}$ \\
\hline & 60 & $0.50 \pm 0.143 \mathrm{aA}$ & $0.33 \pm 0.089 \mathrm{aA}$ & $0.12 \pm 0.056^{\mathrm{aA}}$ \\
\hline & 150 & $0.55 \pm 0.137^{\mathrm{aA}}$ & $0.31 \pm 0.101^{\mathrm{aA}}$ & $0.14 \pm 0.053^{\mathrm{aA}}$ \\
\hline \multirow[t]{4}{*}{$\mathrm{Pb}$} & 0 & $1.90 \pm 0.464 \mathrm{aA}$ & $1.14 \pm 0.331^{\mathrm{abA}}$ & $0.08 \pm 0.027^{b A}$ \\
\hline & 30 & $2.11 \pm 0.539 \mathrm{aA}$ & $1.40 \pm 0.378^{a b A}$ & $0.17 \pm 0.051^{\mathrm{bA}}$ \\
\hline & 60 & $2.13 \pm 0.523 \mathrm{aA}$ & $1.41 \pm 0.426 \mathrm{abA}$ & $0.27 \pm 0.135 \mathrm{bA}$ \\
\hline & 150 & $2.03 \pm 0.499 \mathrm{aA}$ & $1.40 \pm 0.381 \mathrm{abA}$ & $0.18 \pm 0.088 \mathrm{bA}$ \\
\hline \multirow[t]{4}{*}{ Ub } & 0 & $7.26 \pm 3.043 \mathrm{aA}$ & $3.48 \pm 0.331^{\mathrm{aA}}$ & $0.86 \pm 0.430 \mathrm{bA}$ \\
\hline & 30 & $8.44 \pm 2.071^{\mathrm{aA}}$ & $6.22 \pm 0.378^{a b A}$ & $1.40 \pm 0.294^{\mathrm{bA}}$ \\
\hline & 60 & $5.31 \pm 2.088^{\mathrm{aA}}$ & $2.75 \pm 0.426 \mathrm{aA}$ & $0.66 \pm 0.232^{\mathrm{aA}}$ \\
\hline & 150 & $5.57 \pm 2.225^{\mathrm{aA}}$ & $2.79 \pm 0.381^{\mathrm{aA}}$ & $1.02 \pm 0.530 \mathrm{aA}$ \\
\hline \multirow[t]{4}{*}{$\mathrm{Cg}$} & 0 & $0.38 \pm 0.094^{\mathrm{aA}}$ & $0.26 \pm 0.090^{a A}$ & $0.12 \pm 0.039 \mathrm{aA}$ \\
\hline & 30 & $0.46 \pm 0.097^{\mathrm{aA}}$ & $0.35 \pm 0.124^{\mathrm{aA}}$ & $0.15 \pm 0,050^{a A}$ \\
\hline & 60 & $0.47 \pm 0.102^{\mathrm{aA}}$ & $0.32 \pm 0.112^{\mathrm{aA}}$ & $0.19 \pm 0.044^{a A}$ \\
\hline & 150 & $0.46 \pm 0.103 \mathrm{aA}$ & $0.30 \pm 0.107^{\mathrm{aA}}$ & $0.14 \pm 0.029^{a A}$ \\
\hline
\end{tabular}

B)

\begin{tabular}{|c|c|c|c|c|c|}
\hline \multirow[t]{2}{*}{ SPECIES } & \multirow{2}{*}{$\begin{array}{l}\text { time } \\
\text { (min) }\end{array}$} & \multicolumn{4}{|l|}{$\mathrm{pH}$} \\
\hline & & 7 & 8 & 9.5 & 11.5 \\
\hline \multirow[t]{4}{*}{$\mathrm{Mh}$} & 0 & $0.23 \pm 0.104^{\mathrm{aA}}$ & $0.31 \pm 0.133^{\mathrm{aA}}$ & $0.24 \pm 0.121^{\mathrm{aA}}$ & $0.62 \pm 0.090 \mathrm{aA}$ \\
\hline & 30 & $0,28 \pm 0.113^{\mathrm{aA}}$ & $0.40 \pm 0.191^{\mathrm{aA}}$ & $0.12 \pm 0.093^{\mathrm{aA}}$ & $0.43 \pm 0.168 \mathrm{aA}$ \\
\hline & 60 & $0.31 \pm 0.120^{\mathrm{aA}}$ & $0.29 \pm 0.130 \mathrm{aA}$ & $0.43 \pm 0.196^{\mathrm{aA}}$ & $0.60 \pm 0.246^{a A}$ \\
\hline & 150 & $0.24 \pm 0.098^{\mathrm{aA}}$ & $0.40 \pm 0.173^{a A}$ & $0.17 \pm 0.112^{\mathrm{aA}}$ & $0.25 \pm 0.192 \mathrm{aA}$ \\
\hline \multirow[t]{4}{*}{$\mathrm{Pb}$} & 0 & $1.41 \pm 0.322^{\mathrm{aA}}$ & $1.82 \pm 0.437 \mathrm{aA}$ & $1.15 \pm 0.579 \mathrm{aA}$ & $2.67 \pm 0.4644^{\mathrm{aA}}$ \\
\hline & 30 & $1.40 \pm 0.279^{a A}$ & $1.78 \pm 0.436^{a A}$ & $0.80 \pm 0.396^{\mathrm{aA}}$ & $1.63 \pm 0.339 \mathrm{aA}$ \\
\hline & 60 & $1.37 \pm 0.372^{\mathrm{aA}}$ & $1.77 \pm 0.424^{\mathrm{aA}}$ & $2.15 \pm 0.363^{\mathrm{aA}}$ & $2.31 \pm 0.511^{\mathrm{aA}}$ \\
\hline & 150 & $1.50 \pm 0.283^{\mathrm{aA}}$ & $1.86 \pm 0.279 \mathrm{aA}$ & $1.26 \pm 0.629 \mathrm{aA}$ & $1.40 \pm 0.701^{\mathrm{aA}}$ \\
\hline \multirow[t]{4}{*}{ Ub } & 0 & $1.57 \pm 0.265^{\mathrm{aA}}$ & $1.40 \pm 0.266^{\mathrm{aA}}$ & $1.83 \pm 0.439^{\mathrm{aA}}$ & $1.58 \pm 0.431^{\mathrm{aA}}$ \\
\hline & 30 & $1.06 \pm 0.307^{\mathrm{aA}}$ & $0.85 \pm 0.189 \mathrm{aA}$ & $0.54 \pm 0.507^{\mathrm{aA}}$ & $1.00 \pm 0.272^{\mathrm{aA}}$ \\
\hline & 60 & $1.59 \pm 0.346^{\mathrm{aA}}$ & $1.40 \pm 0.288^{a A}$ & $1.65 \pm 0.318^{\mathrm{aA}}$ & $2.40 \pm 0.480^{\mathrm{aA}}$ \\
\hline & 150 & $1.28 \pm 0.196^{\mathrm{aA}}$ & $1.40 \pm 0.242^{\mathrm{aA}}$ & $1.36 \pm 0.300^{\mathrm{aA}}$ & $1.73 \pm 0.384^{\mathrm{aA}}$ \\
\hline \multirow[t]{4}{*}{$\mathrm{Cg}$} & 0 & $0.15 \pm 0.040^{\mathrm{aA}}$ & $0.15 \pm 0.040^{a A}$ & $0.19 \pm 0.073 \mathrm{abA}$ & $0.56 \pm 0.146^{\mathrm{bA}}$ \\
\hline & 30 & $0.12 \pm 0,053^{\mathrm{aA}}$ & $0.19 \pm 0.060^{\mathrm{aA}}$ & $0.14 \pm 0.040^{\mathrm{aA}}$ & $0.39 \pm 0.099 \mathrm{aA}$ \\
\hline & 60 & $0.10 \pm 0.028^{\mathrm{aA}}$ & $0.12 \pm 0.026^{a A}$ & $0.23 \pm 0.053^{a A}$ & $0.53 \pm 0.099 \mathrm{bA}$ \\
\hline & 150 & $0.16 \pm 0.046^{\mathrm{aA}}$ & $0.20 \pm 0.060^{a A}$ & $0.23 \pm 0.060^{\mathrm{abA}}$ & $0.50 \pm 0.105^{b A}$ \\
\hline
\end{tabular}


The assays were carried out at $25^{\circ} \mathrm{C}$ during $0,30,60$, and $150 \mathrm{~min}$ for extracts recovered from fishery waste of Merluccius hubbsi (Mh), Percophis brasiliensis $(\mathrm{Pb})$, Urophyis brasiliensis $(\mathrm{Ub})$ and Cynoscion guatucupa $(\mathrm{Cg})$. Specific enzyme activity (SA) was expressed as $\mathrm{U} / \mathrm{mg}$ of soluble protein. Values indicate means and standard error and were calculated from three replicates. Means within the same rows with different small letters are significantly different. Means within the same columns with different capital letters are significantly different $(p \otimes 0.05)$.

Optimum temperature and thermostability

The effect of temperature on the proteinase activity of stomach samples is shown in Table 3A. The significant highest values of enzymatic activity were observed at 30 and $50{ }^{\circ} \mathrm{C}$ for $\mathrm{Mh}, \mathrm{Pb}$, and $\mathrm{Ub}$. The enzymes of $\mathrm{Cg}$ showed significantly high activity at $50{ }^{\circ} \mathrm{C}$. The stomach enzymes of $\mathrm{Mh}, \mathrm{Pb}$, and $\mathrm{Cg}$ were stable for 150 minutes at 10,30 , and $50^{\circ} \mathrm{C}$. The enzymes of $\mathrm{Ub}$ were stable at 10 and $30{ }^{\circ} \mathrm{C}$, and these extracts stand out for maintained a high activity at $30^{\circ} \mathrm{C}$, from $11.78 \mathrm{U} / \mathrm{mg}$ protein (time $0 \mathrm{~min}$ ) to $11.6 \mathrm{U} / \mathrm{mg}$ protein (time $150 \mathrm{~min}$ ). Similar results were reported for Sardinella aurita (Ben Khaled et al. 2011 ), S. sagax (Castillo-Yañez et al. 2004), P. lineatus (Gomez et al. 2018) and P. gigas (Vannabun et al. 2014) where optimum temperatures were between $33-55^{\circ} \mathrm{C}$.

In the present study, proteinase activity for $C$. guatucupa stomach extracts at $70{ }^{\circ} \mathrm{C}$ was almost null. However, acid proteinases for the other studied species had activity after $150 \mathrm{~min}$ at $\mathrm{pH}$ 2, so a denaturation assay was performed to determine the temperature where these enzymes lose more than $95 \%$ of their initial activity. Obtained results showed that proteinase residual activities for enzymes of $\mathrm{Mh}, \mathrm{Pb}$, and Ub were less than $5 \%$ at $80{ }^{\circ} \mathrm{C}$ after 5,10 y 20 minutes of pre-incubation, respectively (data not shown). High temperatures can cause the loss of catalytic activity because the quaternary structure of the protein is unfolded, and consequently, inactivation of the enzymes occur (Klomklao et al. 2011).

The effect of temperature on the proteinase activity of intestine-ceca is shown in Table 3B. Optimum temperature was $50^{\circ} \mathrm{C}$ for enzymes of all species. The maximum value observed was $5.05 \mathrm{U} / \mathrm{mg}$ protein for the crude extract of Ub. The enzymes of all fishes were thermostable at 10 and $30{ }^{\circ} \mathrm{C}$ during 150 minutes, without significant differences. However, in all cases, the values of specific enzymatic activity were highest at $30^{\circ} \mathrm{C}$. After 150 minutes at $30{ }^{\circ} \mathrm{C}$, the enzymes of $\mathrm{Cg}$ doubled their activity initial while the enzymes of the other species maintained their enzymatic activity initial.

After 30 minutes at $50{ }^{\circ} \mathrm{C}$, there was a pronounced and significatively loss of specific activity for enzymes of all species. These values are correlated with what was found for the digestive proteinases of S. guttatus (Rengasamy et al. 2016), P. gigas (Vannabun et al. 2014), B. panamensis (Rios-Herrera et al. 2019), S. longiceps (Ramkumar et al. 2018) and $S$. dumerili (Oliveira et al. 2017), where the optimum temperature was between $45-60{ }^{\circ} \mathrm{C}$. However, in those previous studies, alkaline proteinases were stable at higher temperatures than in this research. These differences may be due to the fact that fish viscera recovered from tropical water species are used for most studies on digestive proteases, such as seer fish, farmed giant catfish, and Indian oil sardine. The four commercial species selected in the present study inhabit cold waters of the Argentine Sea over Southwestern Atlantic waters (23-55 ${ }^{\circ} \mathrm{S}$ ), where water temperatures are usually below $20^{\circ} \mathrm{C}$ (Allega et al. 2019).

For all studied species, the alkaline proteinase activity was almost null at $70{ }^{\circ} \mathrm{C}$, thus, the denaturation assay was not necessary. Proteinase residual activity was less than $5 \%$ after 30 min for enzymes of $\mathrm{Pb}$ and $\mathrm{Ub}$, and after 150 minutes for enzymes of $\mathrm{Cg}$. Alkaline proteinases of Mh showed low enzyme activity and values did not show significant differences at different time incubation (data not shown).

\section{Table 3}

Table 3. Specific proteinase activity at different conditions of temperature for stomach (A) and intestine extracts (B) 


\begin{tabular}{|c|c|c|c|c|c|}
\hline \multirow[t]{2}{*}{ SPECIES } & \multirow{2}{*}{$\begin{array}{l}\text { time } \\
\text { (min) }\end{array}$} & \multicolumn{4}{|c|}{ TEMPERATURE $\left({ }^{\circ} \mathrm{C}\right)$} \\
\hline & & 10 & 30 & 50 & 70 \\
\hline \multirow[t]{4}{*}{ Mh } & 0 & $0.34 \pm 0.063^{\mathrm{aA}}$ & $0.65 \pm 0.157^{\mathrm{aA}}$ & $0.59 \pm 0.143^{\mathrm{aA}}$ & $0.21 \pm 0.027^{\mathrm{aA}}$ \\
\hline & 30 & $0.34 \pm 0.059 \mathrm{aA}$ & $0.57 \pm 0.140 \mathrm{aA}$ & $0.46 \pm 0.089 \mathrm{aA}$ & $0.14 \pm 0.061^{\mathrm{aA}}$ \\
\hline & 60 & $0.34 \pm 0.059 \mathrm{aA}$ & $0.49 \pm 0.106^{\mathrm{aA}}$ & $0.35 \pm 0.082^{\mathrm{aA}}$ & $0.08 \pm 0.026^{a A}$ \\
\hline & 150 & $0.33 \pm 0.072^{\mathrm{aA}}$ & $0.55 \pm 0.122^{\mathrm{aA}}$ & $0.17 \pm 0.021^{\mathrm{aA}}$ & $0.08 \pm 0.030^{a A}$ \\
\hline \multirow[t]{4}{*}{$\mathrm{Pb}$} & 0 & $2.06 \pm 0.470 \mathrm{aA}$ & $3.14 \pm 0.750^{\mathrm{aA}}$ & $3.63 \pm 0.714^{\mathrm{aA}}$ & $1.35 \pm 0.395^{\mathrm{aA}}$ \\
\hline & 30 & $1.22 \pm 0.493^{\mathrm{abA}}$ & $3.37 \pm 0.858 \mathrm{aA}$ & $4.39 \pm 1.071^{\mathrm{aA}}$ & $0.04 \pm 0.020 \mathrm{bB}$ \\
\hline & 60 & $1.94 \pm 0.531^{\mathrm{abA}}$ & $3.34 \pm 0.732^{\mathrm{aA}}$ & $2.70 \pm 0.679 \mathrm{aA}$ & $0.13 \pm 0.094 b B$ \\
\hline & 150 & $1.78 \pm 0.453^{\mathrm{abA}}$ & $3.15 \pm 0.777 \mathrm{aA}$ & $2.17 \pm 0.561 \mathrm{abA}$ & $0.15 \pm 0.116^{b B}$ \\
\hline \multirow[t]{4}{*}{ Ub } & 0 & $6.72 \pm 1.417^{\mathrm{abA}}$ & $11.78 \pm 3.878^{\mathrm{aA}}$ & $11.79 \pm 4.118^{\mathrm{aA}}$ & $2.42 \pm 0.651^{\mathrm{bA}}$ \\
\hline & 30 & $7.51 \pm 3.142^{\mathrm{abA}}$ & $11.58 \pm 3.392^{\mathrm{bA}}$ & $2.71 \pm 0.823^{\mathrm{aAB}}$ & $2.92 \pm 2.129 \mathrm{aA}$ \\
\hline & 60 & $6.73 \pm 2.417^{\mathrm{abA}}$ & $11.97 \pm 3.609^{\mathrm{aA}}$ & $2.41 \pm 0.147^{\mathrm{cbAB}}$ & $0.37 \pm 0.531^{\mathrm{cA}}$ \\
\hline & 150 & $7.54 \pm 2.291^{\mathrm{aA}}$ & $11.6 \pm 3.576^{\mathrm{aA}}$ & $1.08 \pm 0.411^{\mathrm{bB}}$ & $0.25 \pm 0.185^{b A}$ \\
\hline \multirow[t]{4}{*}{$\mathrm{Cg}$} & 0 & $0.33 \pm 0.118^{\mathrm{abA}}$ & $0.61 \pm 0.179^{a b ~ A}$ & $0.79 \pm 0.165^{\mathrm{aA}}$ & $0.11 \pm 0.034^{\mathrm{bA}}$ \\
\hline & 30 & $0.31 \pm 0.089^{\mathrm{abA}}$ & $0.67 \pm 0.127^{\mathrm{aA}}$ & $0.62 \pm 0.110^{\mathrm{aA}}$ & $0.04 \pm 0.016^{\mathrm{bAB}}$ \\
\hline & 60 & $0.32 \pm 0.119^{\mathrm{abA}}$ & $0.62 \pm 0.171^{\mathrm{aA}}$ & $0.47 \pm 0.082^{a b A}$ & $0.02 \pm 0.006^{\mathrm{bB}}$ \\
\hline & 150 & $0.33 \pm 0.116^{\mathrm{abA}}$ & $0.57 \pm 0.174^{\mathrm{aA}}$ & $0.43 \pm 0.088^{a b A}$ & $0.01 \pm 0.005^{b B}$ \\
\hline
\end{tabular}

B)

\begin{tabular}{|c|c|c|c|c|c|}
\hline \multirow[t]{2}{*}{ SPECIES } & \multirow{2}{*}{$\begin{array}{l}\text { time } \\
\text { (min) }\end{array}$} & \multicolumn{4}{|c|}{ TEMPERATURE $\left({ }^{\circ} \mathrm{C}\right)$} \\
\hline & & 10 & 30 & 50 & 70 \\
\hline \multirow[t]{4}{*}{$\mathrm{Mh}$} & 0 & $0.14 \pm 0.059 \mathrm{aA}$ & $0.44 \pm 0.197 a b A$ & $1.30 \pm 0.430 \mathrm{bA}$ & $0.14 \pm 0.058 \mathrm{aA}$ \\
\hline & 30 & $0.12 \pm 0.043 a b A$ & $0.40 \pm 0.137 \mathrm{aA}$ & $0.13 \pm 0.031 \mathrm{ab} \mathrm{B}$ & $0.04 \pm 0.028 \mathrm{bA}$ \\
\hline & 60 & $0.12 \pm 0.054 \mathrm{aA}$ & $0.36 \pm 0.157 \mathrm{aA}$ & $0.19 \pm 0.079 a \mathrm{aAB}$ & $0.07 \pm 0.013 \mathrm{aA}$ \\
\hline & 150 & $0.08 \pm 0.030 \mathrm{aA}$ & $0.41 \pm 0.216 \mathrm{aA}$ & $0.18 \pm 0.103 \mathrm{aB}$ & $0.06 \pm 0.031 \mathrm{aA}$ \\
\hline \multirow[t]{4}{*}{$\mathrm{Pb}$} & 0 & $0.51 \pm 0.167 \mathrm{aA}$ & $1.90 \pm 0.461 \mathrm{abA}$ & $3.11 \pm 0.556 \mathrm{bA}$ & $0.96 \pm 0.247 \mathrm{aA}$ \\
\hline & 30 & $0.44 \pm 0.13 \mathrm{aA}$ & $2.29 \pm 0.430 \mathrm{bA}$ & $1.47 \pm 0.100 \mathrm{bB}$ & $0.04 \pm 0.010 \mathrm{aB}$ \\
\hline & 60 & $0.54 \pm 0.154 \mathrm{aA}$ & $2.14 \pm 0.481 \mathrm{bA}$ & $0.22 \pm 0.110 \mathrm{aC}$ & $0.05 \pm 0.029 \mathrm{aB}$ \\
\hline & 150 & $0.57 \pm 0.187 \mathrm{aA}$ & $2.09 \pm 0.472 \mathrm{bA}$ & $0.04 \pm 0.008 \mathrm{cC}$ & $0.00 \pm 0.000 \mathrm{cC}$ \\
\hline \multirow[t]{4}{*}{$\mathrm{Ub}$} & 0 & $0.51 \pm 0.242 \mathrm{aA}$ & $1.75 \pm 0.331 \mathrm{bA}$ & $5.05 \pm 0.710 \mathrm{cA}$ & $0.48 \pm 0.081 \mathrm{aA}$ \\
\hline & 30 & $0.40 \pm 0.18 \mathrm{abA}$ & $1.67 \pm 0.340 \mathrm{aA}$ & $0.49 \pm 0.076 \mathrm{bAB}$ & $0.02 \pm 0.020 \mathrm{aB}$ \\
\hline & 60 & $0.33 \pm 0.136 \mathrm{aA}$ & $1.58 \pm 0.256 \mathrm{bA}$ & $0.29 \pm 0.109 \mathrm{aAB}$ & $0.20 \pm 0.106 \mathrm{aAB}$ \\
\hline & 150 & $0.35 \pm 0.161 \mathrm{abA}$ & $1.49 \pm 0.292 \mathrm{aA}$ & $0.58 \pm 0.379 a b B$ & $0.04 \pm 0.020 \mathrm{bAB}$ \\
\hline \multirow[t]{4}{*}{$\mathrm{Cg}$} & 0 & $0.20 \pm 0.099 a A$ & $0.20 \pm 0.069 \mathrm{aA}$ & $1.90 \pm 0.471 \mathrm{bA}$ & $0.34 \pm 0.091 \mathrm{abA}$ \\
\hline & 30 & $0.09 \pm 0.054 \mathrm{aA}$ & $0.32 \pm 0.075 \mathrm{abA}$ & $1.38 \pm 0.330 \mathrm{bA}$ & $0.18 \pm 0.069 \mathrm{aAB}$ \\
\hline & 60 & $0.06 \pm 0.014 \mathrm{aA}$ & $0.42 \pm 0.131 \mathrm{bA}$ & $0.88 \pm 0.197 \mathrm{bA}$ & $0.08 \pm 0.026 \mathrm{aAB}$ \\
\hline & 150 & $0.08 \pm 0.019 \mathrm{aA}$ & $0.39 \pm 0.122 \mathrm{bA}$ & $0.07 \pm 0.031 \mathrm{aB}$ & $0.01 \pm 0.012 \mathrm{aB}$ \\
\hline
\end{tabular}

The assays were carried out at $25^{\circ} \mathrm{C}$ during $0,30,60$ and $150 \mathrm{~min}$ at $\mathrm{pH} 2$ for stomach extracts and pH 8 for intestine extracts recovered from fishery waste of Merluccius hubbsi (Mh), Percophis brasiliensis ( $\mathrm{Pb})$, Urophyis brasiliensis (Ub) and Cynoscion guatucupa (Cg). Specific enzyme activity (SA) was expressed as $\mathrm{U} / \mathrm{mg}$ of soluble protein. Values indicate means and standard error from three replicates. Means within the same rows with different small letters are significantly different. Means within the same columns with different capital letters are significantly different $(p \otimes 0.05)$. 
Optimum temperature and stability of fish enzymes are associated with the habitat characteristics (Nalinanon et al. 2008). In this sense, enzymes of the species studied in this work were stable at low temperature $\left(10^{\circ} \mathrm{C}\right.$, Table $3 \mathrm{~A}$ and $\left.3 \mathrm{~B}\right)$. However, all the tested enzymes also showed high activity at high temperatures $\left(30-50^{\circ} \mathrm{C}\right)$. These ectothermic species can adopt different strategies according to habitat characteristics to maintain a normal level of proteolysis at temperatures well below than of endothermic species. For example, they increase enzyme production to compensate for reduced kinetic efficiency (Brier et al. 2007). Although acid and alkaline proteases showed stability at $10{ }^{\circ} \mathrm{C}$, the enzyme activity at this temperature showed low values.

In recent years, the interest by finding new thermostable enzymes has grown mainly because various industrial processes occur at high temperatures using enzymes from mesophilic sources. Fish proteases, for example, are widely used in several industries to make a change in taste, texture, and appearance of the product and in waste recovery. Also, they are used in food, pharmaceutical, and laundry industries, leather treatment and bioremediation processes.

Thermostable enzymes have certain benefits for industrial processes, such as a high reaction rate and a longer half-life. Previous studies have reported that recovered proteases can be used for reducing the viscosity of stick-water poured outside in the processing of fishmeal (Castillo-Yañez et al. 2004) and they can be useful in some food processing operations where low temperatures and rapid inactivation of proteases are needed like the production of protein hydrolysates (Castro-Ceseńa et al. 2012; Rios-Herrera et al. 2019). Furthermore, the lower denaturation temperature for fish enzymes, especially alkaline proteinases showed in the present study, with respect to microbial enzymes could be an advantage in industrial processes because it implies an energy saving in the process. In this sense, based on its characteristics of thermal stability and denaturation, the enzymes recovered from $\mathrm{Mh}, \mathrm{Pb}, \mathrm{Cg}$, and $\mathrm{Ub}$ could be appropriate for technological uses.

\section{Conclusions}

This study displays novel results about biomolecules, as proteases of wastes, from four commercial fish species from the Atlantic Southwest Ocean; it's the first research that compares activity from proteases recovered from Merluccius hubbsi, Percophis brasiliensis, Urophyis brasiliensis, and Cynoscion guatucupa. This study demonstrated patterns of proteinases varying activity depending on location in the digestive tract, temperature, and pH conditions and it was demonstrated that viscera of the four tested commercial species are an important source of proteolytic enzymes that provided acid and alkaline proteinases with stability at low and moderates temperatures, and maintenance of its catalytic capabilities in a wide range of pHs. These recovered enzymes could be used as biocatalysts in industrial bioprocesses with different biotechnological applications, reducing costs, adding value to the fisheries wastes, and contributing to the reduction of environmental pollution. Future research regarding partial purification and immobilization of these enzymes, scale-up studies, and techno-economic evaluation is needed to be carried out. Improved utilization of the resource not only could provide several and novel useful higher-value products, but also improve economical returns to the fishing industry without increasing fishing pressure.

\section{Declarations}

\section{Ethics approval and consent to participate Not applicable}

Consent for publication Not applicable

Availability of data and materials Not applicable

Competing interests The authors declare that they have no competing interests

Funding This work was supported by Mar del Plata National University [EXA 874-18 and 875-18]

Authors' contributions ISF designed and performed the assays, analyzed and interpreted the data, wrote the paper. LAB performed the assays, analyzed and interpreted the data. NAP designed the assays, edited the paper. EC interpreted the data and edited the paper. AVFG designed and performed the assays, analyzed and interpreted the data, edited the paper and is the corresponding author for journal. All authors read and approved the final manuscript.

\section{Acknowledgments}

This study is part of Ivana Friedman's graduate PhD Thesis (National University of Mar del Plata, Argentina) supported by CONICET fellowship.

\section{References}

1. Allega L, Braverman M, Cabreira AG, Campodónico S, Colonello JH, Derisio C, Di Mauro R, Firp CA, Gaitán EN, Hozbor MC, Irusta CG, Lutz VA, Marí NR, Militelli MI, Moriondo Danovaro PI, Navarro G, Orlando P, Pájaro M, Prandoni N, Prosdocimi L, Reta R, Rico R, Riestra CM, Segura V , Schejter L, Schiariti A, Souto VS, Verón E (2019) Estado del conocimiento biológico pesquero de los principales recursos vivos y su ambiente, con relación a la exploración hidrocarburífera en la Zona Económica Exclusiva Argentina y adyacencias. Eds. Colonello, J. H., Prosdocimi, L. \& Allega, L. Mar del Plata: Instituto nacional de Investigación y Desarrollo Pesquero INIDEP, p 119.

2. Alonso RB, Romero MA, Ocampo Reinaldo M, Bustelo PE, Medina Al, Gonzalez R (2019) The opportunistic sense: The diet of Argentine hake Merluccius hubbsi reflects changes in prey availability. Reg Stud Mar Sci 27:100540. doi:10.1016/j.rsma.2019.100540.

3. Anson ML (1938) The estimation of pepsin, trypsin, papain, and cathepsin with hemoglobin. J Gen Physiol 22:79-89. doi:10.1085/jgp.22.1.79.

4. Aspevik T, Oterhals $\AA$, Rønning SB, Altintzoglou T, Wubshet SG, Gildberg A, Afseth N, Whitaker RD, Lindberg D (2017) Valorization of Proteins from Co- and By-Products from the Fish and Meat Industry. Top Curr Chem Cham 375:53-53. doi: 10.1007/s41061-017-0143-6.

5. Atta MB, El-Hamed A, El-Said S, Keshk SA (2017) Characterization and Purification of Alkaline Proteases From Viscera of Silver Carp

(Hypophthalmichthys molitrix) Fish. Assiut J Agric Sci 48:40-54. doi:10.21608/AJAS.2017.7572.

Page $8 / 10$ 
6. Ben Khaled H, Ghorbel-Bellaaj O, Hmidet N, Jellouli K, El-Hadj Ali N, Ghorbel S, Nasri M (2011) A novel aspartic protease from the viscera of Sardinelle (Sardinella aurita): Purification and characterisation. Food Chem 128:847-853. doi:10.1016/j.foodchem.2011.03.104.

7. Bkhairia I, Mhamdi S, Jridi M, Nasri M (2016) New acidic proteases from Liza aurata viscera: Characterization and application in gelatin production. Int J Biol Macromol 92:533-542. doi:10.1016/j.ijbiomac.2016.07.063.

8. Bovcon ND, Góngora ME, Marinao C, González-Zevallos D (2013) Composición de las capturas y descartes generados en la pesca de merluza común Merluccius hubbsi y langostino patagónico Pleoticus muelleri: un caso de estudio en la flota fresquera de altura del Golfo San Jorge, Chubut, Argentina. Rev Biol Mar Oceanogr 48:303-319. doi:10.4067/S0718-19572013000200010.

9. Bradford M (1976) A rapid and sensitive method for the quantitation of microgram quantities of protein utilizing the principle of protein-dye binding. Anal Biochem 72: 248-254. doi:10.1016/0003-2697(76)90527-3.

10. Brier S, Maria G, Carginale V, Capasso A, Wu Y, Taylor RM, Borotto NB, Capasso C, Engen JR (2007) Purification and characterization of pepsins A1 and A2 from the Antarctic rock cod Trematomus bernacchii. FEBS Journal 274: 6152-6166. doi:10.1111/j.1742-4658.2007.06136.x.

11. Castillo-Yañez FJ, Pacheco-Aguilar R, Garcia-Carreño FL, de los Angeles Navarrete-Del M (2004) Characterization of acidic proteolytic enzymes from Monterey sardine (Sardinops sagax caerulea) viscera. Food Chem 85:343-350. doi:10.1016/j.foodchem.2003.07.008.

12. Castro Ceseńa AB, Sánchez-Saavedra MP, Márquez-Rocha FJ (2012) Characterization and partial purification of proteolytic enzymes from sardine byproducts to obtain concentrated hydrolysates. Food Chem 135:583-589. doi:10.1016/j.foodchem.2012.05.024.

13. Falcón-Hidalgo B, Forrellat-Barrios A, Farnés OC, Hernández KU (2011) Digestive enzymes of two freshwater fishes (Limia vittata and Gambusia punctata) with different dietary preferences at three developmental stages. Comp Biochem Physiol B 158:136-141. doi:10.1016/j.cbpb.2010.10.009.

14. FAO (2018) Food and Agriculture Organization of the United Nations. The state of world fisheries and aquaculture. Meeting the sustainable development goals. http://www.fao.org/3/i9540en/19540EN.pdf. Accessed 29 May 2020.

15. Ferraro V, Carvalho AP, Piccirillo C, Santos MM, Castro PM, Pintado ME (2013) Extraction of high added value biological compounds from sardine, sardinetype fish and mackerel canning residues-A review. Mater Sci Eng C 33:3111-3120. doi:10.1016/j.msec.2013.04.003.

16. García-Carreño FL (1992) The digestive proteases of langostilla (Pleuroncodes planipes, Decapoda): their partial characterization, and the effect of feed on their composition. Comp Biochem Physiol B 103:575-578. doi:10.1016/0305-0491(92)90373-Y.

17. Gioda CR, Pretto A, Freitas C de S, Leitemperger J, Loro VL, Lazzari R, Lissner LA, Baldisserotto B, Salbego J (2017) Different feeding habits influence the activity of digestive enzymes in freshwater fish. Ciênc Rural 47. doi:10.1590/0103-8478cr20160113.

18. Gomez AVA, Gomez G, Chamorro E, Bustillo S, Leiva LC (2018) Digestive aspartic proteases from sábalo (Prochilodus lineatus): Characterization and application for collagen extraction. Food Chem 269:610-617. doi:10.1016/j.foodchem.2018.07.043.

19. Hidalgo MC, Urea E, Sanz A (1999) Comparative study of digestive enzymes in fish with different nutritional habits. Proteolytic and amylase activities. Aquaculture 170:267-283. doi:10.1016/S0044-8486(98)00413-X.

20. Irusta G, Macchi GJ, Louge E, Rodrigues KA, Villarino F, Santos B, Simonazzi MA (2016) Biology and fishery of the Argentine hake (Merluccius hubbsi). Instituto Nacional de Investigación y Desarrollo Pesquero. Revista de Investigación y Desarrollo Pesquero. 28:9-36.

21. Jesús-Ramirez F, Álvarez-González CA, Nolasco-Soria HG, Peña E, Martínez-García R, Camarillo-Coop S, Conway K, Pohlenz C (2017) Caracterización parcial de proteasas digestivas del chucumite (Centropomus parallelus). Hidrobiológica 27:419-427.

22. Khantaphant S, Benjakul S (2008) Comparative study on the proteases from fish pyloric caeca and the use for production of gelatin hydrolysate with antioxidative activity. Comp Biochem Physiol B Biochem Mol Biol 151:410-419. doi:10.1016/j.cbpb.2008.08.011.

23. Kim S-K, Dewapriya P (2014) Enzymes from fish processing waste materials and their commercial applications. In: Seafood Processing By-Products. Springer, pp 183-196. doi:10.1007/978-1-4614-9590-1_10.

24. Klomklao S (2008) Digestive proteinases from marine organisms and their applications. Songklanakarin J Sci Technol. 30:37-46.

25. Klomklao S, Benjakul S, Kishimura H, Chaijan M (2011) 24 kDa Trypsin: A predominant protease purified from the viscera of hybrid catfish (Clarias macrocephalus x Clarias gariepinus). Food Chem 129:739-746. doi:10.1016/j.foodchem.2011.05.014.

26. Kuddus M (2018) Cold-active enzymes in food biotechnology: An updated mini review. J Appl Biol Biotechnol 6:58-63. doi:10.7324/jabb.2018.60310.

27. Lamas DL, Yeannes MI, Massa AE (2015) Partial purification of proteolytic enzymes and characterization of trypsin from Merluccius hubbsi by-products. Int J Food Nutr Sci 4:121-130.

28. Lamas DL, Yeannes MI, Massa AE (2017) Alkaline trypsin from the viscera and heads of Engraulis anchoita: partial purification and characterization. BioTechnologia 98:103-112. doi:10.5114/bta.2017.68309.

29. Martínez AU, López FM, Álvarez-González CA, Perales-García N (2011) Aplicaciones a la mejora de la utilización nutritiva del alimento en cíclidos cultivados en México. Av En Nutr Acuicola, pp 46-104.

30. Martínez-Cárdenas L, Álvarez-González CA, Hernández-Almeida OU, Frías-Quintana CA, Ponce-Palafox JT, Castillo-Vargasmachuca S (2017) Partial Characterization of Digestive Proteases in the Green Cichlid, Cichlasoma beani. Fishes 2:4. doi:10.3390/fishes2010004.

31. Merino-Contreras ML, Sánchez-Morales F, Jiménez-Badillo ML, Peña-Marín ES, Álvarez-González CA (2018) Partial characterization of digestive proteases in sheepshead, Archosargus probatocephalus (Spariformes: Sparidae). Neotropical Ichthyol 16:1-11. doi:10.1590/1982-0224-20180020.

32. Milessi A, Marí N (2012) Ecología trófica del pez palo, Percophis brasiliensis (Quoy y Gaimard, 1825) en el ecosistema costero Argentino-Uruguayo (34 S$\left.41^{\circ} \mathrm{S}\right)$. Mar Fish Sci MAFIS 21:61-72.

33. Mo WY, Man YB, Wong MH (2018) Use of food waste, fish waste and food processing waste for China's aquaculture industry: Needs and challenge. Sci Total Environ 613:635-643. doi:10.1016/j.scitotenv.2017.08.321.

Page 9/10 
34. Nalinanon S, Benjakul S, Visessanguan W, Kishimura H (2008) Tuna pepsin: characteristics and its use for collagen extraction from the skin of threadfin bream (Nemipterus spp.). J Food Sci 73:C413-C419. doi:10.1111/j.1750-3841.2008.00777.x.

35. Natalia Y, Hashim R, Ali A, Chong A (2004) Characterization of digestive enzymes in a carnivorous ornamental fish, the Asian bony tongue Scleropages formosus (Osteoglossidae). Aquaculture 233:305-320. doi:10.1016/j.aquaculture.2003.08.012.

36. Oliveira VM, Nascimento TP, Assis CRD, Bezerra RS, Porto ALF (2017) Study on enzymes of industrial interest in digestive viscera: Greater amberjack (Seriola dumerili). J Coast Life Med 5:233-238. doi:10.12980/jclm.5.2017j6-300.

37. Olsen RL, Toppe J, Karunasagar I (2014) Challenges and realistic opportunities in the use of by-products from processing of fish and shellfish. Trends Food Sci Technol 36:144-151. doi:10.1016/j.tifs.2014.01.007.

38. Pereira N de LA, Fernandez Gimenez AV (2016) Revalorización de subproductos de la pesca: Estado Actual en Argentina y otros países de América Latina. Libro. Editor Académica Española, p 27.

39. Prosdocimi L, Monsalvo M, Martínez Puljak G (2019) Informe Anual Variado Costero, 2018. Dirección de Planificación y Gestión de Pesquerías, Secretaría de Agroindustria, MAGyP. As. INFORME GP N $01 / 2019$.

https://magyp.gob.ar/sitio/areas/pesca_maritima/informes/pesquerias/_archivos//000010_Variado\%20costero/000019\%20Variado\%20Costero\%20Anu; Accessed 10 April 2019.

40. Pujante IM, Díaz-López M, Mancera JM, Moyano FJ (2017) Characterization of digestive enzymes protease and alpha-amylase activities in the thicklipped grey mullet (Chelon labrosus, Risso 1827). Aquac Res 48:367-376. doi:10.1111/are.13038.

41. R Development Core Team, 2015. R: a language and environment for statistical computing. The R foundation for statistical computing, Vienna, Austria. http://www.R-project.org

42. Ramkumar A, Sivakumar N, Gujarathi AM, Victor R (2018) Production of thermotolerant, detergent stable alkaline protease using the gut waste of Sardinella longiceps as a substrate: Optimization and characterization. Sci Rep 8:1-15. doi:10.1038/s41598-018-30155-9.

43. Rengasamy G, Jebaraj DM, Veeraraghavan VP, Krishna S (2016) Characterization, Partial Purification of Alkaline Protease from Intestinal Waste of Scomberomorus Guttatus and Production of Laundry Detergent with Alkaline Protease Additive. Indian J Pharm Educ Res 50: S59-S67. doi:10.5530/ijper.50.2.19.

44. Rios-Herrera GD, Ruiz IO, Hernández C, Valdez-Ortiz A, Sandoval-Gallardo JM, Martínez-Montaño E, Ramírez-Pérez JS, Salazar-Leyva JA (2019) Chihuil Sea Catfish Bagre panamensis Viscera as a New Source of Serine Proteases: Semi-purification, Biochemical Characterization and Application for Protein Hydrolysates Production. Waste Biomass Valorization 1-13. doi:10.1007/s12649-019-00895-4.

45. RStudio Team, 2016. RStudio: Integrated Development for R (Version 1.2.5033). RStudio, Inc., Boston, MA URL http://www.rstudio.com

46. Sahu BB, Barik NK, Paikaray A, Agnibesh A, Mohapatra S, Jayasankar P (2016) Fish Waste Bio-Refinery Products: Its application in Organic Farming. Int J Environ Agric Biotechnol 1:837-843. doi:10.22161/ijeab/1.4.30.

47. Simpson BK (2000) Digestive proteinases from marine animals. FOOD Sci Technol-N Y-MARCEL DEKKER- 191-214.

48. Stauffer CE (1989) Enzyme assays for food scientists. Van Nostand Reinhold/AVI. New York, USA.

49. Välimaa A-L, Mäkinen S, Mattila P, Pihlanto A, Mäki M, Hiidenhovi J (2019) Fish and fish side streams are valuable sources of high-value components. Food Qual Saf 3:209-226. doi:10.1093/fqsafe/fyz024.

50. van Beilen JB, Li Z (2002) Enzyme technology: an overview. Curr Opin Biotechnol 13:338-344. doi:10.1016/S0958-1669(02)00334-8.

51. Vannabun A, Ketnawa S, Phongthai S, Benjakul S, Rawdkuen S (2014) Characterization of acid and alkaline proteases from viscera of farmed giant catfish. Food Biosci 6:9-16. doi:10.1016/j.fbio.2014.01.001.

52. Viola MN, Riccialdelli L, Jaureguizar A, Panarello HO, Cappozzo HL (2018) Variation in the isotopic composition of striped weakfish Cynoscion guatucupa of the Southwest Atlantic Ocean in response to dietary shifts. Braz J Biol 78:202-210. doi:10.1590/1519-6984.01416.

53. Xiong DM, Xie CX, Zhang HJ, Liu HP (2011) Digestive enzymes along digestive tract of a carnivorous fish Glyptosternum maculatum (Sisoridae, Siluriformes). J Anim Physiol Anim Nutr 95:56-64.

\section{Supplementary Files}

This is a list of supplementary files associated with this preprint. Click to download.

- GraphAbs920x346127kbFriedmanetal.jpg 